\title{
Clinical guidelines for traumatic brain injuries in children and boys
}

\author{
Hojjat Derakhshanfar (1), Elham Pourbakhtyaran (1), Samane Rahimi (1), Samira
} Sayyah (1), Zahra Soltantooyeh (2), Fereshteh Karbasian (1)

(1) Department of Pediatric Emergency Medicine, Shahid Beheshti University of Medical Sciences, Tehran, Iran; (2) Mofid Children Hospital, Tehran, Iran

This article is distributed under the terms of the Creative Commons Attribution Noncommercial License (CC BY-NC 4.0) which permits any noncommercial use, distribution, and reproduction in any medium, provided the original author(s) and source are credited.

\begin{abstract}
The main aim of management of pediatric traumatic brain injury (TBI) is to hold normal ranges for optimizing the most proper outcomes. However, to provide physiologic requirements to an injured brain it is very important to enhance the quality of recovery and minimize secondary injuries. Within this study it is tried to identify the most proper guidelines for management of pediatric TBI. A comprehensive research was conducted on biomedical and pharmacological bibliographic database of life sciences such as PubMed, EMBASE, MEDLINE, LILACS database, global independent network of Cochrane, Science Direct and global health library of Global Index Medicus (GIM). By referencing these databases, a literature review was carried out through combining various recent studies in terms of pediatric traumatic brain injury, epidemiology, management and related clinical guidelines in accordance with articles covering this recommendations from 2000 to 2019. Main objective of this study was to provide a comprehensive review of available clinical practice guidelines for TBI. These guidelines can be administered especially for pediatric population to improve the quality of clinical practice for TBI. These guidelines of TBI could be applied worldwide despite different traditional demographic and geographic boundaries, which could affect pediatric populations in various ranges of ages. Accordingly, advances in civil foundations and reforms of health policies may hopefully decrease pediatric TBI socioeconomic burdens.
\end{abstract}

Key Words: Pediatric, traumatic brain injury, TBI management, clinical guidelines.

Eur J Transl Myol 30 (1): xx1-x12, 2020

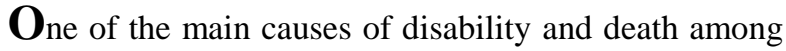
children is traumatic brain injury (TBI). A wide range of traumatic injuries to the layers of scalp, the bony structure of skull and the brain may result from TBI. These kinds of injuries are not the same as those in adults in both pathophysiology and managements. ${ }^{1}$ These dissimilarities are because of structural changes related to age, injury mechanisms related to child physical ability and also the difficulty of neurological assessment in pediatric populations. The scalp consists of five layers, which have large number of blood vessels. Thus, it could be one of the main causes of fatal blood loss when injured. Furthermore, even small amount of blood loss in a baby, toddler and small child that happen without any evident external bleeding, could cause hemorrhagic shock. ${ }^{2}$ Anyway, in children these kinds of injuries may induce special pathological response to injured brain with specific physical symptoms of neurological problems. Progression of medical imaging techniques enhanced health care quality by helping healthcare providers in assessment and identification of children with TBI. Specifically, magnetic resonance imaging (MRI) special facilities improved diagnostic accuracy, and thus proper treatment selection, preventing of adverse side effects like post-traumatic seizures and other brain dysfunctions. ${ }^{3}$

The incidence rate of pediatric TBI is not equal in various geographical areas, being significantly higher in low income countries. In accordance with the global statistics, more than $90 \%$ of injuries among pediatric population happens in low and middle income countries, ninety percent of these injuries being inadverted. ${ }^{4}$ The main causes of pediatric TBI in low and middle income countries are motor-vehicle crashes due to large development of unsafe transportation systems and motorization. ${ }^{5}$ Consequently, the vulnerability of children against traumatic injuries and especially TBIs is higher than other populations. Additionally, the TBI consequences would developed to serious disability with related financial and emotional large costs. ${ }^{6}$ 


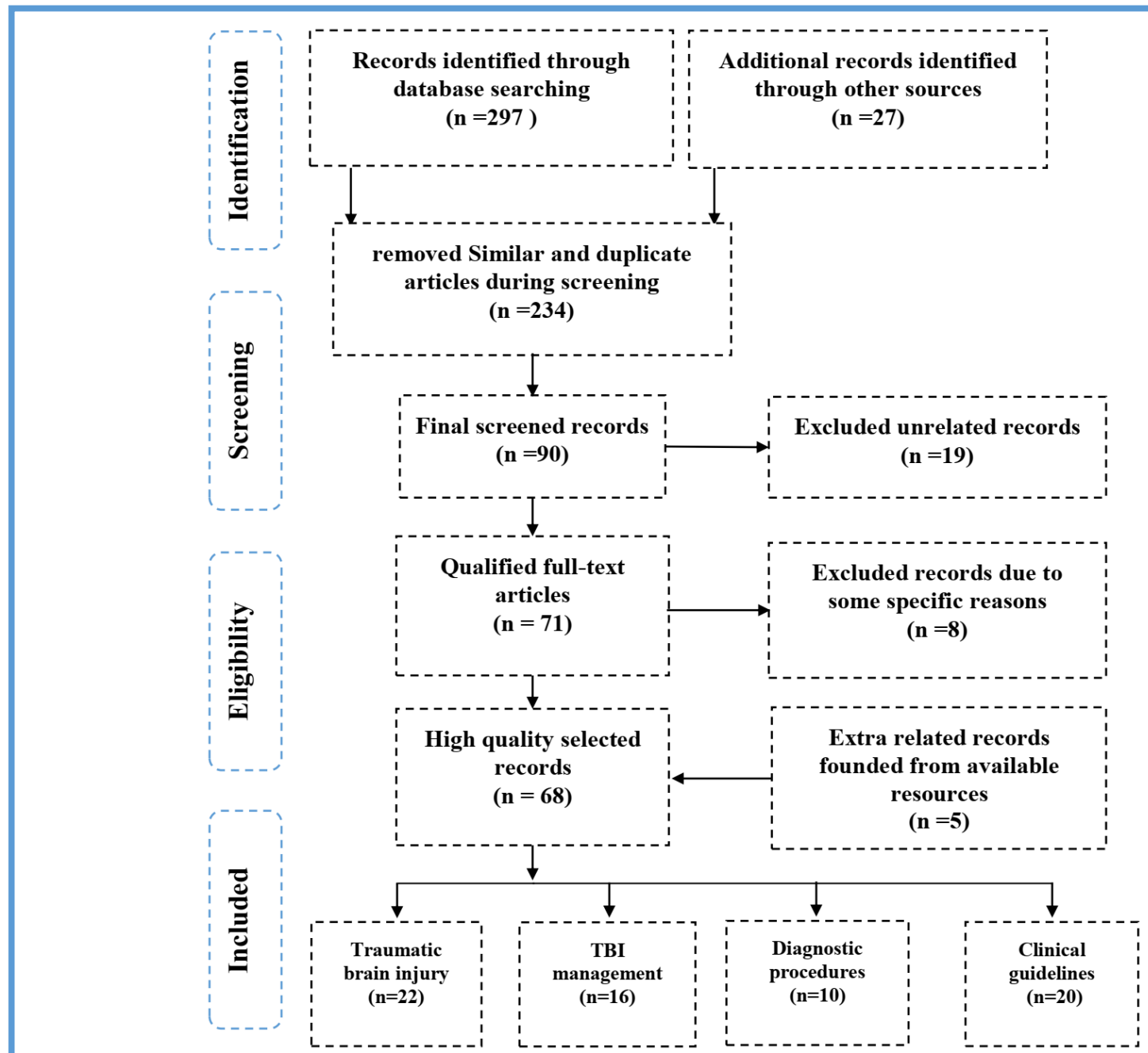

Fig. 1 Schematic diagram of the process of selecting reviewed papers based on PRISMA method.

For improving the outcomes of TBI management among low and middle income populations, beside care progression, initiatives of injury prevention, precise rehabilitation services and strong organized trauma systems, clinical practice guidelines of have an essential role. ${ }^{7}$ Following up good-practice medical guidelines could improve outcome of TBIs management. Performance of advanced medical guidelines of TBI among adults seems to be main causes of decrement of fatality rate in case of hospital care ${ }^{8}$ In addition, some other studies have shown that the clinical outcomes of TBI management could be improved by following up and administering the guidelines of Brain Trauma Foundation (BTF) within adult as well as pediatric populations..$^{9,10}$ Anyway, applying the most proper clinical practice guidelines for acute TBI management in low and middle income countries is a big challenge. In this regard, one of the main restrictions is lack of proper access to resources for preparing proper guidelines on TBI. On the other hand, the existing gaps among the resources and the essential capacity of related resources in addition with the trauma systems variability often could not be covered easily. ${ }^{11,12}$ Initial management of the acute airway as well as prescribing most appropriate sedative agents, the most suitable ventilation and also the potent strategies of hyperosmolar therapy were picked out mainly for preserving normal cerebral perfusion pressure (CPP). Anyway, some novel and effective clinical practice guidelines for serious management of pediatric TBI should be created. Additionally, creating some specific guidelines mainly for pediatric population, could be the main capability of improving the quality of clinical practice guidelines of TBI. The main objective of this study is to evaluate the existing clinical practice guidelines quality for proper diagnosis and management of pediatric TBI. ${ }^{13}$

\section{Materials and Methods}

A comprehensive rsearch was conducted on biomedical and pharmacological bibliographic database of life sciences, such as PubMed, EMBASE, MEDLINE, LILACS database, global independent network of Cochrane, Science Direct and global health library of Global Index Medicus (GIM). By referencing these 
databases, a universal literature review was carried out through combining various recent studies in terms of pediatric traumatic brain injury, epidemiology, management and related clinical guidelines in accordance with various related articles published from 2000 to 2019 which could cover this area of recommendations. Totally 324 articles were checked briefly which about 117 of them were deleted due to less related content to the objective of the study. Finally, after deleting some other articles with subjective weakness and adding some other articles through additional databases, 68 articles were chosen for more detailed review. For achieving the objectives of this study, the candidate articles in terms of evidence-based medicine $(\mathrm{EBM})$, traumatic brain injury (TBI), traumatic injuries involving the intracranial, scalp and skull structures and clinical practice guidelines were identified. The schematic diagram of article selection procedure is demonstrated in figure 1 that was designed accprding to the PRISMA method.

\section{Results}

\section{TBI epidemiology}

Among all kinds of traumatic injuries, damages of brain are the major that could cause permanent disability or death. In accordance with Centers for Disease Control and Prevention (CDC) ${ }^{14}$ any year 475,000 U.S. persons with an age lower than 14 years undergo TBI. About ninety percent of them return to their home after a mild intercession safely, but seven percent would be hospitalized and three percent die due to severity of injuries. The emergency visits at the emergency medicine departments in children younger than four years ar more common than in other age groups. Only a low rate of them would be hospitalized because of their severe conditions. It should be noted that, the death rate among younger children who have BTI is more common than among olders. ${ }^{14}$ Based on available literature the potential of being hurt with traumatic brain injuries among boys is higer than among girls. ${ }^{15}$ The age is one of the factors that could affect main mechanisms of TBI among pediatric populations. As an instance, the accidental falling would be the main causes of TBI among pediatric population at the age group of $0-14$ years. ${ }^{16}$ In children who are at age group of $0-4$ years the main causes of being injured is not just falling from a height but also due to motor vehicle accidents. It's while in children within the age group of 4-8 years would be injured not only due to motor vehicle accidents and falling from heights but it would be happening because of other transportation injuries like bicycle incidents. Pediatric abusive head trauma (AHT) could be seen among population of age group of 0-2 years more than other age groups. Among these injured young infants about $0.03 \%$ would be hospitalized. ${ }^{17,18}$

Table 1. The scores of Pediatric Glasgow Coma Score $(P G C S)^{20}$

\begin{tabular}{|c|c|c|c|c|}
\hline Age Group & & Less than 23 months & 2 to 5 years & Over 5 years \\
\hline & Score & & & \\
\hline \multirow{5}{*}{$\begin{array}{l}\text { Best verbal } \\
\text { response }\end{array}$} & 1 & No response & No response & No response \\
\hline & 2 & Grunts & Grunts & Unclear sounds \\
\hline & 3 & $\begin{array}{l}\text { Screaming or/and crying } \\
\text { at inappropriate times }\end{array}$ & Screams or/and cries & $\begin{array}{c}\text { Inconvenient phrases or } \\
\text { words }\end{array}$ \\
\hline & 4 & Load cries & $\begin{array}{l}\text { Inconvenient phrases } \\
\text { or words }\end{array}$ & Disoriented and converses \\
\hline & 5 & $\begin{array}{l}\text { Appropriate smile and } \\
\text { coo }\end{array}$ & $\begin{array}{c}\text { Appropriate phrases } \\
\text { and words }\end{array}$ & Oriented and converses \\
\hline \multicolumn{5}{|c|}{ Age group } \\
\hline & $\begin{array}{l}\text { The } \\
\text { score }\end{array}$ & \multicolumn{2}{|c|}{ Less than one year } & Over one year \\
\hline \multirow{4}{*}{$\begin{array}{c}\text { Eye } \\
\text { opening }\end{array}$} & 1 & \multicolumn{2}{|l|}{ No response } & No response \\
\hline & 2 & \multicolumn{2}{|c|}{ To pain } & To pain \\
\hline & 3 & \multicolumn{2}{|l|}{ To shout } & To verbal command \\
\hline & 4 & \multicolumn{2}{|c|}{ Spontaneously } & Spontaneously \\
\hline \multirow{6}{*}{$\begin{array}{l}\text { Best motor } \\
\text { response }\end{array}$} & 1 & \multicolumn{2}{|c|}{ No response } & No response \\
\hline & 2 & \multicolumn{2}{|c|}{ Abnormal deployment } & Abnormal deployment \\
\hline & 3 & \multirow{2}{*}{\multicolumn{2}{|c|}{$\begin{array}{c}\text { Abnormal posturing } \\
\text { Withdrawal reflex }\end{array}$}} & Abnormal posturing \\
\hline & 4 & & & Withdrawal reflex \\
\hline & 5 & \multicolumn{2}{|c|}{ Localizes to pain } & Localizes to pain \\
\hline & 6 & \multicolumn{2}{|c|}{ Involuntary movements } & Obeys \\
\hline
\end{tabular}




\section{Specifying characteristics of injury}

Based on age and progression the clinical presentation of children with TBI are not fixed and would change with the trauma severity. According to analized reviews, the Pediatric Glasgow Coma Score (PGCS) is generally used to evaluate consciousness level and to define severity of the head injuries (Table 1). ${ }^{19}$

In general, focal neurologic signs would appeared at the injury time that would be considered as indicators of further advancement of pathological changes. The changes gradually occur in accordance with anatomy and age-specific characteristics of face, brain, neck and skull. These make children very sensitive to injuries that do not happen in adults (Table 2). The children brain structure is a combination of high plasticity and deformity that has peculiar biomechanical characteristics, very relevant for pediatric TBI. Consequently, in children the absorption of external forces is higher in comparison to adults. The rigidity of infant skull is minimal, so the open sutures would act as joints which could cause a slight degree of movement as response to mechanical stress. ${ }^{21,22}$.

Anyway, even during normal delivery intra and extracranial injuries would happen. On the other hand, intracerebral hemorrhage could happen during vaginal deliveries due to traction and compression applied on the fetal head when passing the birth canal, in particular if obstetric instruments are applied. Further, infants are prone to fall into situations like subgaleal hemorrhage and cephalohematoma. ${ }^{23}$

Within this age group, the abnormal condition of hypoxemia and low birth weight are possible risk factors for intraventricular bleeding. However, these risk factors

Table 2. : Properties of injuries based on age and progression. Derived from Takashi A, et al.(2017) ${ }^{22}$

\begin{tabular}{|c|c|c|c|c|c|c|c|}
\hline \multirow{2}{*}{$\begin{array}{l}\text { Age Group } \\
\text { Head trauma } \\
\text { during delivery }\end{array}$} & \multirow[b]{2}{*}{ 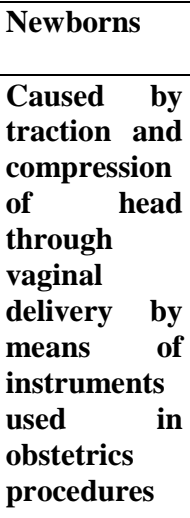 } & \multicolumn{2}{|l|}{ Infants } & \multicolumn{2}{|c|}{$\begin{array}{c}\text { Toddlers } \\
\text { And School children } \\
\end{array}$} & \multicolumn{2}{|l|}{ Adolescents } \\
\hline & & $\begin{array}{l}\text { Head } \\
\text { injury } \\
\text { caused } \\
\text { through } \\
\text { accident }\end{array}$ & $\begin{array}{l}\text { Induced due to } \\
\text { unsuitable } \\
\text { child care } \\
\text { practices }\end{array}$ & $\begin{array}{l}\text { Head } \\
\text { injury } \\
\text { caused } \\
\text { through } \\
\text { accident }\end{array}$ & $\begin{array}{l}\text { The rate of } \\
\text { accidents } \\
\text { will increase } \\
\text { as a } \\
\text { consequence } \\
\text { of } \\
\text { progression } \\
\text { of motor } \\
\text { riding } \\
\text { ability of } \\
\text { children }\end{array}$ & $\begin{array}{l}\text { Motorcycle } \\
\text { and bike } \\
\text { accidents }\end{array}$ & $\begin{array}{l}\text { The } \\
\text { prevention } \\
\text { knowledge } \\
\text { should be } \\
\text { enhanced }\end{array}$ \\
\hline $\begin{array}{l}\text { Intracerebral } \\
\text { hemorrhage }\end{array}$ & & $\begin{array}{l}\text { Pediatric } \\
\text { abusive } \\
\text { head } \\
\text { trauma } \\
\text { (AHT) }\end{array}$ & & & & & \\
\hline Cephalohematoma & & & & & $\begin{array}{l}\text { The rate of } \\
\text { traffic- } \\
\text { related } \\
\text { pedestrian } \\
\text { injuries is } \\
\text { high in this } \\
\text { age group }\end{array}$ & & \\
\hline $\begin{array}{l}\text { Subgaleal } \\
\text { hemorrhage }\end{array}$ & $\begin{array}{l}\text { Abnormally } \\
\text { low level of } \\
\text { oxygen in the } \\
\text { blood and } \\
\text { lower weight } \\
\text { during the } \\
\text { birth procedure } \\
\text { proce risk } \\
\text { are factors for } \\
\text { intracerebral } \\
\text { hemorrhage }\end{array}$ & & & & & & \\
\hline
\end{tabular}


must be distinguished from bleeding disorder and pediatric abusive head trauma (PAHT). Uncontrollable shaking during delivery could cause small deformation within the skull. On the other hand, the high plastic property of the skull would result in share of forces amongst the adjacent cortical tissue and vessels, the skull and brain. These forces which are shared would cause vessels to bear sharing and stretching injuries and also the functional tissue in the brain bear parenchyma. ${ }^{24}$

Compared with their body size, the size of children head is larger than in adults. For this reasons, the possibility of head being impacted in pediatric TBI is higher in comparison with adults. However, the relation among the size of body and head will continuously decrease following the age increasing. Additionally, due to the fact that the weight of head in comparison with other body parts is high, the head vulnerable potential to TBI is higher which could cause various the external forces. The distribution of the existing white matter within the deeper tissues of the brain which have a layer of myelin with, is not the same among newborns and adults. ${ }^{25}$

The brain of newborn is containing large amount of water, but a brain which is myelinated is more denseness because of increasingly decrement of the water content and the advancement of the process of myelination. During the procedure of age progression, various areas of the brain would have different amount of myelination. It should be noted that, the process of myelination within these areas follows up an organized pattern with posterior-anterior and caudocranial predominance. The rate of traumatic forces absorption based on myelination degree will be various, somehow the TBI susceptibility would be increased in regions where there are unmyelinated areas. ${ }^{26}$

The potential of sinuses in absorption of higher amounts of energy during the progression process would be higher; hence, less amount of direct energy would be exerted to the brain and skull. Consequently, along with the development of the face and gradual progression of paranasal sinus, the exerted damages would be restricted. The medical condition of frontal bossing among younger children could cause the increment of the force which would directly exerted to the frontal bone of the skull and underlying brain parenchyma. On other hand, along with increasing age, the progression of facial growth in both downward and forward directions, would cause the increment of the possibility of fractures of midface. ${ }^{27}$

\section{TBI Clinical Characteristics and Diagnosis}

Novel researches have recommended that precise diagnosis, acute management and appropriate rehabilitation should be considered within an overall guideline for applying a more proper management procedure of TBI. In this regard, the main causes of happening these kinds of injuries should be specified. ${ }^{28}$ In this regard, the most possible components of TBI must be specified which include; acute traumatic intraparenchymal hemorrhage (IPH), extraparenchymal vascular injuries and vascular injuries. However, intraparenchymal hemorrhage (IPH) include intracerebral hemorrhage (ICH), the brain diffuses axonal injury (DAI) and intraventricular bleeding. Extraparenchymal vascular injuries are including traumatic blood accumulation of epidural hematoma $(\mathrm{EDH})$, subdural hematoma $(\mathrm{SDH})$, intraventricular bleeding and subarachnoid hemorrhage (SAH). On the other hand, vascular injuries are including false aneurysm, dural arteriovenous fistula (dAVF), carotidcavernous sinus fistula $(\mathrm{CCF})$ and vascular dissection. ${ }^{29}$

\section{Guidelines on management of airway in TBI patients}

Based on the neurological scale of GCS the process of quick tracheal intubation in an unconscious pediatric TBI patient is recommended to be used for proper control of airway, sufficient management of increased intracranial pressure (ICP), could barricade hypoxemia as a significant cause of secondary brain injury. ${ }^{30}$. As guided, along with proper management of airway appropriate sedative or analgesic agents should be applied. In this regard, for achieving the most effective intervention of airway, the appropriate selection of sedative agents with sufficient dosage is recommended too.

It should be noted that, preserving both pressures of cerebral perfusion and mean arterial is recommended to be considered as the major vital factors. ${ }^{30,31}$ One group of these agents that could be applied adequately are benzodiazepines which proven to be beneficial due to their antiepileptic, amnesic and anxiolytic characteristics. On the other hand, respiratory depression as one of the main side effects should be prevented. Additionally, the sedation process would be prolonged from a metabolites development. $^{31,32}$

\section{The strategies of ventilation in TBI patients}

For minimizing or/and prevention of secondary brain injury after conducting an optimized sedation and providing a secure airway, preparing an impressive ventilation is demanded. Due to thea fact that the application of hyperventilation could cause cerebral vasoconstriction syndrome, decrease cerebral blood flow and brain oxygenation, it would induce cerebral ischemia. Consequently, in children with TBI, the application of hyperventilation is not recommended at all. ${ }^{33}$ Cerebral ischemia is proportionally associated with the extent of hyperventilation. It should be noted that, among pediatric TBI, a high rate of severe hypocapnia is is related to high rate ofmortality. ${ }^{34}$

For considering hyperventilation for patients with persistent intracranial hypertension, brain ischemia must be preempted and progressive intraoperative neurophysiological monitoring should be initiated. ${ }^{35}$ The main reason for conducting conservative care procedures of ventilation is the increased risks of lung injury. However, the main objectives of conducting proper ventilation in management of pediatric TBI are to prevent hypocapnia and hypoxia. ${ }^{36}$ 


\section{Pediatric clinical guidelines for traumatic brain injuries}

Eur J Transl Myol 30 (1): xx1-x12, 2020

\section{Primary brain injury}

The fracture of skull

The procedure of management of fractures of skull among children should be carried out more cautiously. The fractures of frontal bone should be managed more critically and need immediate repair. However, the TBI cases which contain fractures would possibly include more than two bones. The potential bone which mostly would involve in linear skull fractures is including temporal, frontal, occipital and mainly parietal bone. ${ }^{37}$ These kinds of fractures could be specified by the presence of ordinary sutures through their special anatomical configuration, existence of complex serrations and ossification signs beside available sutures. One the main clinical characteristics which could be applied indirectly in diagnostic procedure, is extracranial hypodermic edema. Additionally, one of the most effective imaging techniques which could be used for diagnosis of linear skull fractures among children is computed tomography (CT) scan with a high sensitivity rate in children under two years. However, this precise technique could specify brain lesions in about $25 \%$ of cases accurately. ${ }^{38}$ Based on the approved novel guidelines in pediatric TBI who are not detected with non-displaced parietal linear skull fracture hospitalization is not required. It's while, in patients who have been detected with further injuries, abusive head trauma or alteration in mental status, hospitalization would be needed. ${ }^{39}$

The simple type of skull fracture which could be induced from concentrate external forces is the most common one in children amongst depressed skull fractures. The most common type of fractures among children under one year are compound fractures which accounts for about ten percent of all fractures. In situation when fractures be observed over cerebral sinuses, for cotroling and prevention of happening post traumatic dural venous sinus thrombosis and progressive epidural hematoma (PEDH), children should be carried to the intensive care unit (ICU). The available guidelines for proper management of surgical procedure of TBI are based on some recommendation on surgical treatment which could be conducted in the following situations: ${ }^{40,41}$

I: The presence of cerebrospinal fluid (CSF) be detected obviously

II: The presence of foreign body be detected clearly

III: The medical removal of damaged or dead local tissue is required immediately

IV: The localized wound is infectious

$\mathrm{V}$ : The process of hematoma emptying is needed

VI: When cosmetic surgery is needed

One of the main independent risk factors for occurrence of seizures that would be induced due to TBI is depressed fracture of the skull. It's while in accordance with recent guidelines, the association of these two mentioned factors could not be potentially be existing. ${ }^{42}$ On the other hand, based on available guidelines in situations when depressed skull fractures which overlaid on the superior longitudinal sinus happened, enhancing the quality of venous blood circulation could significantly improve the function of nervous system. ${ }^{43}$ The fracture of basal skull would be seen in children hardly ever. In children whose facial skeleton are not developed completely yet, happening basal skull fracture (BSF) at any rates could cause blood vessels and cranial nerve injuries. ${ }^{44}$

These kinds of fractures would be presented as pediatric bacterial meningitis. However, in accordance with approved guidelines precise assessment of clinical symptoms and signs is necessary approximately in all cases. Within their study Alhelali et al. ${ }^{45}$ by investigating the association of BSFs and mortality in pediatric TBI demonstrated that these kinds of fractures could be happening in about a quarter of patients. One other potential kind of fractures which would be happen is the fracture of temporal bone which could be seen in about $33 \%$ of the patients. ${ }^{45}$

\section{Craniocerebral erosion}

Craniocerebral erosion is a kind of skull fractures which could grow and usually could be happen because of the ordinary progression of cystic masses which are filled with cerebrospinal fluid. This kind of fracture is a rare head injury complication that commonly comes with the parietal bone linear fractures in children younger than 36 months. In growing newborns, infants or children under 36 months, the growing skull fractures or cerebral herniation could magnify the line of fracture through the thick membrane of Dura. These fractures are happening because of pulsative pressure through lesions which are inhered to the skull inner table which would simplify nutritional deficiencies along the edges of the bone. ${ }^{46}$ Within the majority of cases, some cosmetic signs like pulsative edema or/and skull depression could be considered as diagnostic factors. It's while some brain problems like seizures and headache would be presented just in few cases. Based on standardized guidelines in surgical treatment of cranioplasty computed tomography image reconstruction could be very effective. Proper comprehension of the pathology of lesions by application of specialized techniques of radiography is recommended to be used for more radical treatment of growing skull fracture (GSF). ${ }^{47}$

\section{Traumatic brain injury $(T B I)$}

Epidural hematoma (EDH)

Due to the fact that, thick membrane of Dura mater among newborn is stuck to the skull inner surface strongly, traumatic epidural hematoma is not very common. Due to the fact that, the middle meningeal artery in newborn children does not exist in the skull and the atrioventricular groove initiated from external common carotid artery is not too deep, its potential in being damaged within TBI is high. ${ }^{48}$ On the other hand, acute epidural hematoma in newborns is essentially venous and frequently would be generated through 
injuries which lie on top of the emissary veins rupture or/and the Dural venous sinuses within the fracture vicinity. In acute epidural hematoma situations, the small space of posterior fossa in the skull is frequently correlated with traumatic occipital condyle fractures which lie on top of the related region from the lateral to the s-shaped hollow curve of pars sigmoid. ${ }^{49}$ The potential of happening arterial acute epidural hematoma which could be swiftly developed and cause a brain herniation and death, must be taken into account seriously. The occurrence of acute epidural hematoma in newborn children would happen mostly within the posterior fossa skull space exactly the same as brain Injury induced from Birth. In general, the acute epidural hematoma does not overpass the line of the suture. On the other hand, in situations when the solid edema of solidified blood induced from pediatric cerebral venous sinus could develop to outside or to the reverse side, so applying intensive care medicine may be needed..$^{50,51}$

\section{Pediatric AHT}

The occurrence rate of pediatric abusive head trauma among children whose age is lower than 12 months is about $0.05 \%$. Formerly, based on the available guidelines pediatric AHT was known as shaken Baby Syndrome or inflicted traumatic brain injury. Abusive head trauma is a kind of head trauma which is incorporating brain parenchyma, spinal cord injury and head injuries. The main mechanism of injury in abusive head trauma could be due to secondary brain injury because of hypotension or/and low oxygen within the body tissues and direct impact or/and vibrate or a mixture of them. ${ }^{52}$

One of the main causes of happening pediatric TBI in population under 24 months is abusive head trauma. Consequently, the consideration of abusive head trauma in diagnostic procedure of children with traumatic injuries is very vital. In this regard, clinical characteristics of abusive head trauma are such as nausea, seizures, decrement of consciousness and delayed milestone. Through applying diagnostic imaging techniques, in about $80 \%$ of cases, the most frequent finding is traumatic subdural hematoma (TSDH). ${ }^{53,54}$

Some other properties of findings of applied imaging techniques are such as cerebral contusion, intracerebral hemorrhage and the presence of blood within the subarachnoid space. It's while traumatic subdural hematoma is not correlated with abusive head trauma at all. On the other hand, the symptoms of seizures could be seen often in abusive head trauma. Additionally, as proved, traumatic scalp injuries, any kind of break in the skull bone and long bone fractures does not have a crucial connection with abusive head trauma. ${ }^{55}$

\section{Secondary traumatic brain injury}

One other significant complications of TBI which is potentially fatal and frequently could be observed in computed tomography scans among pediatric abusive head trauma is cerebral edema. Due to the lack of CSF in cerebral edema patients, the findings of CT scan would be prepared more swiftly among children. Based on their findings, a quite benign course of the disease among children could be observed in comparison with adults. ${ }^{56}$ Because of the presence of the developing mechanism of biological process of autoregulatory for supplying the blood to the brain, the vulnerability of children to hyperemia in the cerebral circulation is higher than adults, which could cause acute intracranial hypertension. ${ }^{57}$ On the other hand, due to the fact that, mean blood pressure of infants is not too high and their blood reserve capacity is not high enough for compensating hypoxia and low blood pressure, any decrement in the blood supply to their brain would be justified. $^{58}$

\section{Final recommendations on pediatric TBI management}

As mentioned before, for achieving the most sufficient outcomes in management of TBI, a proper diagnostic method should be available. One of the main existing scientifically proven invasive techniques for proper monitoring of the pressure inside the skull is using the sensor of intraparenchymal hemorrhage which could be applied in children for detection of traumatic brain injury. ${ }^{59}$ As instance, within their study Alkhoury et al. ${ }^{60}$ reported that the application of this monitoring method could significantly decrease the mortality rate among children with TBI. ${ }^{53,54}$ The overall effect of cerebral blood flow to the brain and the blood pressure inside the skull on TBI outcomes among adults is appropriately known. It's while, there is not any comprehensive studies on determining the perfusion pressure of the brain among children. So more precise investigation is recommended to be conducted in this regard. ${ }^{60}$

The overall evaluation of potent guidelines for proper management of TBI among various age group of children population were conducted based on the final qualitative articles which selected for precise review. Obtained data from various areas showed that in any countries based on their economic condition some guidelines are available that are not the same in low, middle and higher income countries. Anyway, the main objective of creating a comprehensive guideline for pediatric traumatic brain injury is due to the fact that this complication is very dangerous and fatal. ${ }^{61}$

The main focus of studies is on initial management, potential rehabilitation, ICU care, subsequent assessments, and the concussion setting evaluation, prehospital care broad spectrum, specialist care and neurosurgical unit care. The initial step at a situation when a pediatric TBI patient visits an emergency medicine department is to determine the severity level of injury through a precise diagnostic procedure. In this regard, for more accurate management of TBI it should be noted that, a more precise diagnosis procedure is demanded which must be conducted in any clinical procedures. One of the main diagnostic procedure which 
could be applied is using imaging techniques in the acute setting. ${ }^{33,62,63}$

Long term guidelines for proper management of pediatric TBI and achieving both intellectual and physical outcomes are recommended to be administered. In this regard, some researchers have proposed an inclusive guiding protocol of multidisciplinary rehabilitation for facilitating and improving the capability of patients to back home or their common daily activities. ${ }^{64}$ One other significant guidance's which is recommended is to set the most proper communication amongst educators, specialists of rehabilitation unit, children and family members. Conducting these kind of cooperation's would provide a more obvious recognition of children functional capabilities and also enhance the possible immediate and reliable long-term outcomes among children. $^{65}$

Brain imaging techniques has a very significant role in the management process of pediatric TBI. The novel magnetic resonance imaging (MRI) modalities like nuclear magnetic resonance (NMR) spectroscopy, susceptibility weighted imaging (SWI), diffusion MRI, diffusion-weighted imaging (DWI) could provide more precise identification of various parameters which would specify improper function of neurological trauma and brain. ${ }^{66}$ On the other hand, these techniques could provide more swift diagnosis of acute or chronic pediatric TBI among the specified population, so administration of various rehabilitation services would be conducted more easily. ${ }^{67}$ Similar to whole findings above, recently the some studies published also is considered these points mentioned ${ }^{68-75}$ Finally, various scopes of management of pediatric TBI are briefly mentioned in Table 3.

\section{Conclusions}

Performing the most appropriate health care procedures for management of pediatric TBI needs a multidisciplinary approach in any management phase. After the primary assessment, quick diagnosis, precise multimodality monitoring and appropriate management of increment of pressure around the brain are required for minimizing or preventing pediatric TBI.

Clinical practice guidelines are useful tools for proper management of pediatric TBI with the potent potential of informing the progression of care systems of happened trauma with the capability of improving the health care

Table 3. Recommendations for management of pediatric TBI. Derived from Sung A, et al. $(2018)^{75}$

\begin{tabular}{|c|c|c|c|c|c|c|c|c|}
\hline \multicolumn{9}{|c|}{ Scopes of pediatric TBI management } \\
\hline $\begin{array}{l}\text { Sedative } \\
\text { choice }\end{array}$ & $\begin{array}{l}\text { Hyper } \\
\text { to be }\end{array}$ & $\begin{array}{l}\text { entilation } \\
\text { pplied }\end{array}$ & $\begin{array}{l}\text { Hyperosmolar } \\
\text { agents } \\
\text { effectiveness }\end{array}$ & $\begin{array}{l}\text { Control of } \\
\text { body } \\
\text { temperature }\end{array}$ & $\begin{array}{c}\text { Diabetes } \\
\text { management }\end{array}$ & $\begin{array}{c}\text { Neuroimaging } \\
\text { indications }\end{array}$ & $\begin{array}{l}\text { Monitoring } \\
\text { pressure } \\
\text { inside the } \\
\text { skull }\end{array}$ & $\begin{array}{c}\text { Preventive } \\
\text { anticonvulsant }\end{array}$ \\
\hline \multicolumn{9}{|c|}{ Clinical considerations } \\
\hline \multicolumn{2}{|c|}{$\begin{array}{l}\text { The average blood } \\
\text { pressure should be } \\
\text { preserved during } \\
\text { the tracheal } \\
\text { intubation and any } \\
\text { other invasive } \\
\text { procedures }\end{array}$} & $\begin{array}{c}\text { Hyperventil } \\
\text { ation could } \\
\text { cause } \\
\text { cerebral } \\
\text { infarction } \\
\text { or/and } \\
\text { ischemic } \\
\text { stroke }\end{array}$ & $\begin{array}{c}\text { The solution } \\
\text { of } 3 \% \\
\text { hypertonic } \\
\text { saline would } \\
\text { decrease the } \\
\text { requirement } \\
\text { for attendant } \\
\text { interventions } \\
\text { for treatment } \\
\text { of } \\
\text { inappropriate } \\
\text { pressure } \\
\text { inside the } \\
\text { skull }\end{array}$ & $\begin{array}{c}\text { Hypothermia } \\
\text { condition } \\
\text { would cause } \\
\text { heart } \\
\text { arrhythmia } \\
\text { and higher } \\
\text { mortality } \\
\text { rate }\end{array}$ & $\begin{array}{l}\text { Higher } \\
\text { levels of } \\
\text { blood } \\
\text { glucose } \\
\text { could } \\
\text { cause } \\
\text { adverse } \\
\text { side } \\
\text { effects }\end{array}$ & $\begin{array}{c}\text { Pediatric } \\
\text { emergency care } \\
\text { applied research } \\
\text { network } \\
\text { (PECARN) } \\
\text { proposes to } \\
\text { immediately } \\
\text { monitor children } \\
\text { based on glasgow } \\
\text { coma scale }\end{array}$ & - & $\begin{array}{l}\text { Whenever post- } \\
\text { traumatic } \\
\text { seizures risk } \\
\text { factors } \\
\text { appeared, } \\
\text { anticonvulsant } \\
\text { agents must be } \\
\text { applied }\end{array}$ \\
\hline \multicolumn{9}{|c|}{ Approved recommendations } \\
\hline \multicolumn{2}{|c|}{$\begin{array}{l}\text { Whenever volume } \\
\text { depletion or } \\
\text { hypotension } \\
\text { appeared, ketamine } \\
\text { should be applied. } \\
\text { Additionally, when } \\
\text { where was an } \\
\text { absence of adrenal } \\
\text { insufficiency, } \\
\text { etomidate must be } \\
\text { considered. }\end{array}$} & $\begin{array}{c}\begin{array}{c}\text { Prevent } \\
\text { from }\end{array} \\
\text { hyperventil } \\
\text { ation } \\
\text { condition } \\
\text { when } \\
\text { partial } \\
\text { pressure of } \\
\text { carbon } \\
\text { dioxide } \\
\text { lower than } \\
300 \mathrm{mmHg}\end{array}$ & $\begin{array}{c}\text { The } \\
\text { recommended } \\
\text { amount of } \\
\text { hypertonic } \\
\text { saline is 3\% }\end{array}$ & $\begin{array}{l}\text { The body } \\
\text { temperature } \\
\text { is } \\
\text { recommende } \\
\text { d to maintain } \\
\text { in normal } \\
\text { condition }\end{array}$ & $\begin{array}{l}\text { The } \\
\text { level of } \\
\text { sugar in } \\
\text { the } \\
\text { blood is } \\
\text { recomm } \\
\text { ended to } \\
\text { be } \\
\text { normal }\end{array}$ & $\begin{array}{c}\text { The clinical } \\
\text { effectiveness of } \\
\text { conducting } \\
\text { PECARN is to help } \\
\text { clinical specialists } \\
\text { in making } \\
\text { emergency decision } \\
\text { or brain imaging }\end{array}$ & $\begin{array}{c}\text { There not } \\
\text { any proved } \\
\text { documents } \\
\text { on ordinary } \\
\text { application } \\
\text { of } \\
\text { monitoring } \\
\text { for } \\
\text { controlling } \\
\text { the pressure } \\
\text { inside the } \\
\text { skull }\end{array}$ & $\begin{array}{l}\text { There is not any } \\
\text { proved } \\
\text { documents for } \\
\text { ordinary } \\
\text { application of } \\
\text { preventive } \\
\text { anticonvulsant } \\
\text { agents }\end{array}$ \\
\hline
\end{tabular}


delivery quality. Through setting the proper guidelines for obtaining the most effective's outcomes for this particular population, a higher improvement in the quality of management of clinical practice guidelines of pediatric TBI will be achieved. Additionally, by focusing on progression process of the most effective guidelines, the opportunity for training and building more skillfulness specialists in administering clinical practice guidelines would be created.

On the other hand, creating more appropriate standardized strategies based on patient's characteristic, common clinical symptoms, presence of increased pressure inside the skull, along with available healthcare resource limitations, could enable clinicians of emergency medicine department and related critical care physicians for proper management of pediatric TBI. In this regard, novel treatment options should be investigated for achieving more effective outcomes.

\section{List of acronyms}

BSF- Basal skull fracture

CSF- Cerebrospinal fluid

CT -Computed tomography

DWI -Diffusion-weighted imaging

GIM -Global Index Medicus

MRI -Magnetic resonance imaging

NMR- Nuclear magnetic resonance

PGCS- Pediatric Glasgow Coma Score

SWI- Susceptibility weighted imaging,

TBI- traumatic brain injury

TSDH- Traumatic subdural hematoma

\section{Authors contributions}

All authors played a substantial role in the conception and/or study design, drafting and finalizing of the manuscript. They agree for all aspects of accuracy and integrity of the work.

\section{Acknowledgments}

None.

\section{Funding}

No funding was obtained for this project.

\section{Conflict of Interest}

The authors declare they have no financial, personal, or other conflicts of interest.

\section{Ethical Publication Statement}

We confirm that we have read the Journal's position on issues involved in ethical publication and affirm that this report is consistent with those guidelines.

\section{Corresponding Author}

Fereshteh Karbasian, Department of Pediatric Emergency Medicine, Shahid Beheshti University of Medical Sciences, Tehran, Iran.Tel: 00982122623716, Email: Karbasian.md@gmail.com

\section{E-mails of co-authors}

Hojjat Derakhshanfar:hojjatderakhshanfar@yahoo.com Elham Pourbakhtyaran: pourbakhtyaran@gmail.com

Samane Rahimi: Samanerahimi@yahoo.com

Samira Sayyah: samirasayyah@yahoo.com

Zahra Soltantooyeh: Zahrasoltantooyeh@gmail.com

\section{References}

1. Allison KM, Byom LJ, Turkstra LS. Traumatic Brain Injury in Children and Adolescents. In A. Johnson \& B. Jacobson (Eds.), Medical SpeechLanguage Pathology (3rd ed.) Thieme: New York. 2017.

2. American Psychiatric Association. Diagnostic and statistical manual of mental disorders (5th ed.). Washington, DC: Author. 2013.

3. Ferrazzano PA, Rosario BL, Wisniewski SR, et al. Use of magnetic resonance imaging in severe pediatric traumatic brain injury: assessment of current practice. J Neurosurg Pediatr 2019:8:1-9.

4. Dewan MC, Mummareddy N, Wellons JC, et al. Epidemiology of Global Pediatric Traumatic Brain Injury: Qualitative Review. World Neurosurgery 2016:91(1878-8769 (Electronic)):497-509.

5. Brazinova A, Rehorcikova V, Taylor MS, et al. Epidemiology of Traumatic Brain Injury in Europe: A Living Systematic Review. Journal of Neurotrauma 2016:(1557-9042 (Electronic)). Epub Aug 25.

6. Leigh ESE, Kevin GFT, Ursula KR. Pediatric Traumatic Brain Injury: Outcomes and Rehabilitation. Textbook of Pediatric Neurosurgery 2017:pp 1-28.

7. Nino S, Elisa RZ. Chronic impact of traumatic brain injury on outcome and quality of life: a narrative review. Crit Care 2016:20:148.

8. Keris V, Lavendelis E, Macane I. Association between implementation of clinical practice guidelines and outcome for traumatic brain injury. World Journal of Surgery 2007:31:1352-5.

9. Vavilala MS, Kernic MA, Wang J, et al. Acute Care Clinical Indicators Associated with Discharge Outcomes in Children with Severe Traumatic Brain Injury. Critical care medicine 2014:42(10):225866.

10. Gupta D, Sharma D, Kannan N, et al. Guideline Adherence and Outcomes in Severe Adult Traumatic Brain Injury for the CHIRAG (Collaborative Head Injury and Guidelines) Study. World Neurosurgery 2016:89:169-79.

11. Patel A, Vieira MM, Abraham J, et al. Quality of the Development of Traumatic Brain Injury Clinical Practice Guidelines: A Systematic Review. PLOS ONE. 2016:11:e0161554.

12. Rubiano AM, Carney N, Chesnut R, et al. Global neurotrauma research challenges and opportunities. Nature 2015:527(7578):S193-S7. 
13. Shruti A, Ricardo GB. Neuroprotective measures in children with traumatic brain injury. World J Crit Care Med 2016:5:36-46.

14. Centers for Disease Control and Prevention (CDC). WISCARS. Leading Causes of Death reports, National and regional, 2015,pp:1999-2013. http://webappa.cdc.gov/cgi-bin/broker.exe Access 2015.9.22.

15. Hari HD, Siddharth C. Management of traumatic brain injury patients. Korean J Anesthesiol 2018:71:12-21.

16. Injury Prevention and Control: Traumatic Brain injury. Centers for Disease Control and Prevention. http://www.cdc.gov/traumaticbraininjury/data/dist _ hosp. html Access 2015

17. Carney N, Totten A. M, O'Reilly C, et al. 2017. Guidelines for the management of severe traumatic brain injury, fourth edition. Neurosurgery 2017;80:6-15.

18. Rhine T, Wade SL, Makoroff KL, et al. Michaud Clinical predictors of outcome following inflicted traumatic brain injury in children $\mathrm{J}$ Trauma Acute Care Surg 73 (4 Suppl. 3), 2012,pp. S248-S253.

19. Timmons S.D, Bee T, Webb S, et al. Hesdorffer Using the abbreviated injury severity and Glasgow coma scale scores to predict 2-week mortality after traumatic brain injury J Trauma 2011;71:1172-8.

20. Campbell JE. Trauma scoring in the prehospital setting. In: International Trauma Life Support - For Prehospital Care Providers. 1st ed. India: Dorling Kindersley. 2009, p. 382.

21. Kochanek P.M, Carney N, Adelson P. D, et al. Guidelines for the acute medical management of severe traumatic brain injury in infants, children, and adolescents - second edition Pediatr Crit Care Med, 2012:13 (Suppl 1), pp. S1-S82.

22. Takashi A, Hiroyuki Y, Akio M. 2017. Pediatric Traumatic Brain Injury: Characteristic Features, Diagnosis, and Management. Neurol Med Chir (Tokyo) 2017:57:82-93.

23. Thomas G, Lionel V, Lamine A, et al. Management of severe traumatic brain injury (first 24 hours). Anaesthesia Critical Care \& Pain Medicine 2018:37:171-86.

24. Stark MJ, Hodyl NA, Belegar VKK, et al. Intrauterine inflammation, cerebral oxygen consumption and susceptibility to early brain injury in very preterm newborns. Arch Dis Child Fetal Neonatal Ed 2016:101:F137-F142.

25. Catherine AF. Management of the paediatric patient with acute head trauma. Paediatr Child Health 2013:18:253-8.

26. Rudy JC, Carl JS. Brain injury biomechanics and abusive head trauma. J Forensic Sci Med 2018;4:91-100.

27. David M, Patrick B, Marvin M. The Significance of Macrocephaly or Enlarging Head Circumference in
Infants with the Triad. Am J Forensic Med Pathol 2015:36:111-20.

28. Alali A. S, Gomez D, Sathya C, et al. Intracranial pressure monitoring among children with severe traumatic brain injury. $\mathrm{J}$ Neurosurg Pediatr 2015:14:1-10.

29. El-Hennawy HM, El-Menyar A, Al-Thani H, et al. 2014. Epidemiology, Causes and Prevention of Car Rollover Crashes with Ejection. Ann Med Health Sci Res 2014:4:495-502.

30. Reto AS. Intensive Care in Traumatic Brain Injury Including Multi-Modal Monitoring and Neuroprotection. MedSci 2019:7;37.

31. Oddo M, Crippa IA, Mehta S, et al. Optimizing sedation in patients with acute brain injury. Critical Care 2016:20:128.

32. Welch TP, Wallendorf MJ, Kharasch ED, et al. Fentanyl and Midazolam Are Ineffective in Reducing Episodic Intracranial Hypertension in Severe Pediatric Traumatic Brain Injury. Crit Care Med 2016:44:809-18.

33. Curley G, Kavanagh BP, Laffey JG. Hypocapnia and the injured brain: more harm than benefit. Crit Care Med 2010:38:1348-59.

34. Wan-Chao Y, Qi W, Lai-Ting C, et al. Therapeutic hypercapnia reduces blood-brain barrier damage possibly via protein kinase $\mathrm{C} \varepsilon$ in rats with lateral fluid percussion injury. $\mathrm{J}$ Neuroinflammation 2019:16;36.

35. Kochanek PM, Carney N, Adelson PD, et al. Guidelines for the acute medical management of severe traumatic brain injury in infants, children, and adolescents-second edition. Pediatr Crit Care Med 2012:13 Suppl 1:S1-82.

36. Agrawal S, Branco RG. Neuroprotective measures in children with traumatic brain injury. World J Crit Care Med 2016:5:36-46.

37. Bonfield CM, Naran S, Adetayo O, et al. Pediatric skull fractures: the need for surgical intervention, characteristics, complications, and outcomes. J Neurosurg Pediatr 2014:14:205-11.

38. Kralik SF, Supakul N, Wu IC, et al. Black bone MRI with 3D reconstruction for the detection of skull fractures in children with suspected abusive head trauma. Neuroradiology 2019;61:81-7.

39. Kommaraju K, Haynes JH, Ritter AM. Evaluating the Role of a Neurosurgery Consultation in Management of Pediatric Isolated Linear Skull Fractures. Pediatr Neurosurg 2019;54:21-7.

40. Te FC, Shih HY, Jui CT. Depressed skull fracture and epidural hematoma resulted from pin-type head holder for craniotomy in children. J Med Sci J Med Sci 2014;34:238-40.

41. Roneeta N, Shruti R, Rana P, et al. Sudden and Persistent Bradycardia: An Unexpected Indicator of Pin-Site Extradural Hematoma in a Pediatric Patient. J Neuroanaesthesiology Critical Care 2018;05:187-9. 
42. Wei-Jun K, Tomor H, Cheng-Li L, et al. Mortality Risk and Risk Factors in Patients with Posttraumatic Epilepsy: A Population-Based Cohort Study. Int $\mathbf{J}$ Environ Res Public Health 2019;16:589.

43. Mohamed MA, Shafik TE, Hisham AA, et al. Depressed Skull Fractures Overlying Dural Venous Sinuses: Management Modalities and Review of Literature. Turk Neurosurg 2019. DOI: 10.5137/1019-5149.JTN.25572-18.2.

44. Taylor DD, Gercel TC. Exosome platform for diagnosis and monitoring of traumatic brain injury. Philosophical Transactions of the Royal Society B: Biological Sciences 2014:369:1652-7

45. Alhelali I, Stewart TC, Foster J, et al. Basal skull fractures are associated with mortality in pediatric severe traumatic brain injury. J Trauma Acute Care Surg 2015:78:1155-61.

46. Saurabh J, Ashok G, Achal S, et al. Growing skull fracture with cerebrospinal fluid fistula: A rare case report and its management strategies. Asian Journal of Neurosurgery 2015:10:3.

47. Prasad GL, Gupta DK, Mahapatra AK, et al. Surgical results of growing skull fractures in children: a single center study of 43 cases. Childs Nerv Syst 2015:31:269-77.

48. You C, Long X, Hu L, et al. Traumatic Posterior Fossa Epidural Hematomas in children: Experience with 48 Cases and a Review of the Literature. J Korean Neurosurg Soc 2019;62:225-31.

49. Louise M. C, Cathy C, Franz EB, et al.. Intellectual, Behavioral, and Social Outcomes of Accidental Traumatic Brain Injury in Early Childhood. Pediatrics 2012:129;2.

50. Arabinda KC, Sabah S, Thomas LS, et al. Consensus statement on abusive head trauma in infants and young children. Pediatric Radiology 2018:48:1048-65.

51. Rosenthal AA, Solomon RJ, Eyerly SA, et al. Traumatic Epidural Hematoma: Patient Characteristics and Management. Am Surg 2017;83:e438-e440.

52. Karibe H, Kameyama M, Hayashi T, et al.. Acute Subdural Hematoma in Infants with Abusive Head Trauma: A Literature Review. Neurol Med Chir (Tokyo). 2016;56:264-73.

53. Shankar V, Rashmi K, Chandrakanta K, et al. PA 18-2-1347 Inflicted traumatic brain injury (ITBI) study- a hidden epidemic. http://dx.doi.org/ 10.1136/injuryprevention-2018-safety.110. 2018

54. Peter JS. Shaken baby syndrome is real. Pediatric Radiology 2018:48;1043-7.

55. Bhardwaj G, Chowdhury V, Jacobs MB, et al. A systematic review of the diagnostic accuracy of ocular signs in pediatric abusive head trauma. Ophtalmology 2010;117:983-92.
56. David K, Caron H, Bizhan A, et al. Hemorrhagic Progression of a Contusion after Traumatic Brain Injury: A Review. Journal Neurotrauma 2012:29;1.

57. Chih-Fen H, Hueng-Chuen F, Cheng-Fu C, et al. Current Approaches to the Treatment of Head Injury in Children. Pediatrics \& Neonatology 2013:54;73-81.

58. Mayumi P, Tiffany G, Daya A, et al. The pathophysiology of traumatic brain injury at a glance. Disease Models \& Mechanisms 2013;6:1307-15.

59. Sujoy B, Girija PR, Ritesh L, et al. Intracranial pressure monitoring in children with severe traumatic brain injury: A retrospective study. Journal of Pediatric Neurosciences 2019:14;7-15.

60. Alkhoury F, kyriakides TC. Intracranial pressure monitoring in children with severe traumatic brain injury: national trauma data bank-based review of outcomes. JAMA Surg 2014;149:544-8.

61. Kochanek P. M, Carney N, Adelson PD, et al. Guidelines for the Acute Medical Management of Severe Traumatic Brain Injury in Infants, Children, and Adolescents-Second Edition. Pediatric Critical Care Medicine 2012:13(Suppl 1):S1-82.

62. Hardcastle N, Benzon HA, Vavilala MS. Update on the 2012 guidelines for the management of pediatric traumatic brain injury - information for the anesthesiologist. Paediatr Anaesth 2014;24:703-10.

63. Roumeliotis N, Dong C, Pettersen G, et al. Hyperosmolar therapy in pediatric traumatic brain injury: a retrospective study. Childs Nerv Syst 2016;32:2363-8.

64. Rebecca MJ, Jennifer JB, Joseph FP, et al. Reducing Head CT Use for Children with Head Injuries in a Community Emergency Department. Pediatrics 2019;139:e20161349

65. Osmond MH, Klassen TP,Wells GA, et al. CATCH: a clinical decision rule for the use of computed tomography in children with minor head injury. CMAJ 2010;182:341-8.

66. Babl FE, Borland ML, Phillips N, et al. Accuracy of PECARN, CATCH, and CHALICE head injury decision rules in children: a prospective cohort study. Lancet 2017;389:2393-402.

67. Easter J. S, Bakes K, Dhaliwal J, et al. Comparison of PECARN, CATCH, and CHALICE rules for children with minor head injury: a prospective cohort study. Ann Emerg Med 2014:64:145-52, 152.e1-5

68. Bordbar A, Mohagheghi P, Yoonesi L, Kalani M, Kashaki M. Value of Physical Examination in the Diagnosis of Developmental Hip Dislocation in Preterm Infants, J Compr Ped. 2018 ; 9:e14049

69. Seraj B,Shahrabi M, Masoumi S, et al. Studying Maxillary Labial Frenulum Types and Their Effect on Median Diastema in 3-6-year-old Children in Tehran Kindergartens.World J Dent 2019:10:93-7. 
70. Saboute M,Kashaki M, Bordbar A, et al.The Incidence of Respiratory Distress Syndrome among Preterm Infants Admitted to Neonatal Intensive Care Unit: A Retrospective Study. Open J Ped 2015;5:285.

71. Mogharrabi S,Ghodsi S,Jabbarzadeh $\mathrm{M}$, et al. Evaluating the Effect of Low Concentrations of. Common Chemical Solutions on Disinfecting Heat. Cured Acrylic-Resin. Adv Dent Oral Health 2019:11:555804

72. Bordbar A, Hadipour M, Kashaki M. Determination of the Prevalence of Patent Ductus Arteriosus in Infants with Very Low Birth Weight Admitted in Hospital during 2011-2016. Prensa Med Argent 2019:105:134.
73. Kashaki M, Alipour R, Saboute M. Changes in Vitamin D Status during the First Two Weeks of Life in Preterm Infants on TPN: A Cross Sectional Study. Prensa Med Argent 2019:105:135.

74. Kashaki M, Bordbar A, Mazouri A, et al. Determination of the Effect of High-Dose Intralipid in Compared to Its Gradual Dose in Very Low Birth Weight Newborns: A Case-control Study. J Pharmaceutical Res Int 2019:30:1-7.

75. Sung ST, Shu-Ling C. Pediatric traumatic brain injury-a review of management strategies. J Emerg Crit Care Med 2018;2:18.

Submission: October 8, 2019

Acceptance: October 30, 2019 